\title{
Combined effects of water quality and stocking density on welfare and growth of rainbow trout (Oncorhynchus mykiss)
}

\author{
Jeannine Person-Le Ruyet ${ }^{1, a}$, Laurent Labbé ${ }^{2}$, Nicolas Le Bayon ${ }^{1}$, Armelle Sévère ${ }^{1}$, Annick Le Roux ${ }^{1}$, \\ Hervé Le Delliou ${ }^{1}$ and Loic Quéméner ${ }^{1}$ \\ Ifremer, UMR 1067-PFOM, Centre de Brest, 29280 Plouzané, France \\ 2 Inra, PEIMA, 29450 Sizun, France
}

Received 4 January 2008; Accepted 10 March 2008

\begin{abstract}
An 84-day experiment assessed the combined effects of two fresh water quality levels (H: $1.71 \pm 0.15 \mathrm{mg}$ $\mathrm{O}_{2} \mathrm{l}^{-1}$ and $0.28 \pm 0.01 \mathrm{mg} \mathrm{l}^{-1}$ total ammonia nitrogen (T-AN), L: $5.15 \pm 0.07 \mathrm{mg} \mathrm{O}_{2} \mathrm{l}^{-1}$ and $0.54 \pm 0.01 \mathrm{mg} \mathrm{T}-\mathrm{AN} \mathrm{l}^{-1}$ ) and 3 stabilized stocking densities: $24.8 \pm 0.2,74.2 \pm 0.5$ and $120.0 \pm 0.9 \mathrm{~kg} \mathrm{~m}^{-3}$ ) on rainbow trout. Fish were fed using demand feeders with rewards proportional to stocking density. Mass increase was significantly affected by water quality and stocking density, being highest in $\mathrm{H}$ water and the lowest at $120 \mathrm{~kg} \mathrm{~m}^{-3}$. There was no significant difference in final weight between 25 and $74 \mathrm{~kg} \mathrm{~m}^{-3}$, but at $120 \mathrm{~kg} \mathrm{~m}^{-3}$ it was $27 \%$ and $19 \%$ lower in $\mathrm{H}$ and $\mathrm{L}$ water respectively than at $25 \mathrm{~kg} \mathrm{~m}^{-3}$. Feed intake (FI) from day 0-85 was significantly affected by water quality, $1.5 \%$ in $\mathrm{H}$ compared to $1.1-1.0$ in L, but there were no significant differences in apparent feed conversion (AFC). FI was not significantly affected by stocking density but AFC was impaired, it increased with stocking density. Marked changes in fish morphology and composition were related to water quality: Condition $\mathrm{K}$ factor and fillet fat content were significantly higher in $\mathrm{H}$ than in L groups. Dorsal and pectoral fin condition was affected by stocking density and water quality: fins were significantly longer and less eroded in L groups and at low stocking density. Physiological measures were within the usual ranges, but differed between treatments. Changes in plasma osmolarity, hydromineral balance $\left(\mathrm{Na}^{+}\right)$and acid base balance $\left(\mathrm{HCO}_{3}^{-}\right)$showed that fish were more affected by water quality than by stocking density. There was no sign of acute stress in acclimated fish as cortisol and glycemia were similar under all experimental conditions. This study highlights the importance of water quality and feeding conditions when considering the effects of stocking density on fish welfare.
\end{abstract}

Key words: Rainbow trout / Water quality / Stocking density / Welfare / Growth

Résumé - Effets combinés de la qualité de l'eau et de la densité d'élevage sur le bien-être et la croissance de la truite arc-en-ciel (Oncorhynchus mykiss). Les effets combinés de deux niveaux de qualité d'eau douce ( $H$ : concentration en oxygène $1,71 \pm 0,15 \mathrm{mg} \mathrm{O}_{2} 1^{-1}$ et $0,28 \pm 0,01 \mathrm{mg} \mathrm{l}^{-1}$ d'azote ammoniacal total (AAT), $L: 5,15 \pm 0,07 \mathrm{mg}$ $\mathrm{O}_{2} 1^{-1}$ et $0,54 \pm 0,01 \mathrm{mg}$ AAT $1^{-1}$ ) et trois densités d'élevage stabilisées à : 24,8 $\pm 0,2,74,2 \pm 0,5$ et $120,0 \pm 0,9 \mathrm{~kg} \mathrm{~m}^{-3}$ ) ont été étudiés chez la truite arc-en-ciel élevée en eau douce pendant 84 jours. Les poissons sont nourris au moyen d'auto-nourrisseurs avec une récompense proportionnelle à la densité. La croissance est significativement affectée par la qualité de l'eau et la densité, elle est la plus élevée en eau de bonne qualité $(\mathrm{H})$, et la plus faible à $120 \mathrm{~kg} \mathrm{~m}^{-3}$. Il n'y a pas de différence significative des poids finaux entre 25 et $74 \mathrm{~kg} \mathrm{~m}^{-3}$, mais à $120 \mathrm{~kg} \mathrm{~m}^{-3}$, ils sont $27 \%(\mathrm{H})$ ou $19 \%$ (L) plus bas que ceux obtenus à $25 \mathrm{~kg} \mathrm{~m}^{-3}$. La prise alimentaire (PA) est significativement affectée par la qualité de l'eau, PA de J0-84 de 1,5\% dans les groupes H contre 1,1-1,0 dans les groupes L, mais il n'y a pas de différence significative du taux de conversion apparent (TCA). Pour la même période, PA n'est pas significativement affectée par la densité alors que TCA augmente avec la densité. Des changements marqués dans la morphologie et la qualité du poisson selon la qualité de l'eau sont observés : le facteur de condition K et la composition en lipides totaux des filets sont significativement plus élevés dans les groupes $\mathrm{H}$ que dans les groupes L. L'état des nageoires dorsales et pectorales est affecté par la densité et la qualité de l'eau : les nageoires sont significativement plus longues et moins érodées dans le groupe $\mathrm{L}$ et à faible densité. Les paramètres physiologiques mesurés sont dans les gammes usuelles mais diffèrent entre les traitements. Les valeurs de l'osmolarité, de l'équilibre hydrominéral $\left(\mathrm{Na}^{+}\right)$et de l'équilibre acide-base $\left(\mathrm{HCO}_{3}^{-}\right)$

${ }^{\text {a }}$ Corresponding author: jperson@ifremer.fr 
du plasma sanguin montrent que les poissons sont plus affectés par la qualité de l'eau que par la densité. Il n'y a pas de signe de stress aigu chez les poissons acclimatés, taux de cortisol et glycémie du plasma similaires pour tous les traitements. Cette étude met en évidence que les effets de la densité d'élevage sur le bien-être du poisson ne peuvent pas être considérés sans référence à la qualité de l'eau et aux conditions d'alimentation.

\section{Introduction}

Stocking density (SD) is a key factor determining the productivity of fin fish aquaculture systems, mainly through the way it maximizes water use. However, high SDs are also a potential source of stress that may limit growth and be harmful for fish welfare when physiological and spatial needs are not adequately met. Increasing scientific, political and public attention is being paid to fish welfare, especially in regard to the quality of life and state of well being of fish in commercial production systems (Conte 2004; Huntingford et al. 2006; Ashley 2007). Different risks to welfare (stressful husbandry practices, disease, water quality) have been extensively discussed, but establishing what is acceptable for the fish and how to quantify welfare using relevant operational indicators remains a major challenge (Ellis et al. 2002; Spoolder et al. 2003; Turnbull et al. 2005; Huntingford et al. 2006; North et al. 2006; Ashley 2007).

Intensive fish farming has been highlighted as an area of particular concern in Europe since the publication of the UK Farm Animal Council's (FAWC) report into the Welfare of Farmed Fish (Anon. 1996), which judged that SDs of $30-40 \mathrm{~kg} \mathrm{~m}^{-3}$ were potentially detrimental to trout welfare This report was followed by several studies on the effects of SD in farmed fish species: rainbow trout (Lefrançois et al. 2001; Boujard et al. 2002; Ellis et al. 2002; Begout-Anras and Lagardère 2004; North et al. 2006a,b), Atlantic salmon (Turnbull et al. 2005), sea bass (Vazanna et al. 2002; Gornati et al. 2004) and sea bream (Montero et al. 1999). In rainbow trout, Ellis et al. (2002) reported that inappropriate densities could negatively impact growth and welfare, and that optimal SD may vary widely as it is highly dependant on rearing system design. In rainbow trout, no effects on growth or mortality were observed between 10 and $80 \mathrm{~kg} \mathrm{~m}^{-3}$ by North et al. (2006a), or between 25 and $100 \mathrm{~kg} \mathrm{~m}^{-3}$ by Boujard et al. (2002) under certain feeding conditions. Observations of growth reduction at high SD were frequently associated with fin damage, though the exact process by which fin damage occurs remains poorly understood. Fin damage is commonly observed in all commercial farmed fish species. The shape and length of fins changes, and the occurrence of injuries (necrosis, splits, rot) can be used as welfare indicators both in experiments and on-farm (Goede and Barton 1990; Latremouille 2003; Hoyle et al. 2007; Noble et al. 2007; Person-Le Ruyet et al. 2004).

Using common experimental facilities and the same fish strain, a French national program examined SD ranging from 25 to $100 \mathrm{~kg} \mathrm{~m}^{-3}$ and showed that: (i) growth may be impaired by high SD when feeding procedures are inadequate (Boujard et al. 2002); (ii) routine metabolic activity, indicative of energy expenditure, was not affected by SD (Lefrançois et al. 2001); and (iii) swimming behaviour changed according to space availability (Begout-Anras and Lagardère 2004). This study concluded that food accessibility was the main factor responsible for density-related growth problems at high SD, and that there was a need to study the effect of water quality because this interacts with SD. The carrying capacity of a given amount of water is determined by the oxygen consumption rate of the fish and their response to ammonia, $\mathrm{CO}_{2}$ and other potentially toxic metabolic wastes that are produced. On farms, reported SD effects are often due to the accumulation of fish metabolites and oxygen depletion, or episodic system failures due to the instability of systems operating at high stocking densities. It has been shown in many fish species that deterioration of water quality leads to a decrease in food intake and growth, and an impairment of physiological functions (Brett 1979; Person-Le Ruyet et al. 1997, 2003a,b, 2004; Pichavant et al. 2001; Lemarié et al. 2004).

The purpose of our 84-day experiment was to assess the combined effects of two levels of water quality (High and Low) and 3 stabilized stocking densities $\left(25,75\right.$ and $\left.120 \mathrm{~kg} \mathrm{~m}^{-3}\right)$ under unrestricted feeding conditions. In the High $(\mathrm{H})$ water, oxygen and ammonia concentrations were kept at levels considered to be optimal. In the Low (L) water there was moderate hypoxia and ammonia accumulation, as commonly observed over short periods on farms (e.g. rearing system failures, overfeeding). The highest SD in our experiment is representative of the upper-limit of intensive trout farming, or densities that might be experienced for a short time during husbandry practices (e.g. crowding before harvest), the intermediate SD tested mimicked a mid-high operational SD for large fish and the lowest SD is indicative of stocking densities that might be used in less intensive production systems (e.g. for producing fish for restocking). Performance was measured using a number of commonly applied production measurements (e.g. survival, weight gain, food conversion), and fish welfare was assessed using physiological and physical indicators, particularly focusing on the incidence of damage to pectoral and dorsal fins.

\section{Materials and methods}

\subsection{Animals and husbandry}

The experiment was conducted at the Le Drennec experimental farm (Brittany, France) using graded immature rainbow trout (autumnal INRA Strain) reared on-site from ova. Fish were randomly assigned to one of 12 groups in tanks where they were acclimated for a month at a stocking density of $40 \mathrm{~kg} \mathrm{~m}^{-3}$. Flow-through tanks of $1 \mathrm{~m}^{3}$ (2 m diameter) were used, supplied with river water and maintained outdoors under natural photoperiod. At the start of the experiment the feeding procedure was changed from belt feeders to computercontrolled demand-feeders (Isometric ${ }^{\circledR}$ ) using the reference reward level of the farm (Boujard et al. 2002). Fish were fed over the entire light phase (12-h access to self-feeder) with a commercial diet, Aqualife $17\left(\right.$ Biomar $\left.^{\circledR}\right)$, composed of $42 \%$ protein and 22\% lipid in \% Dry Matter (DM). 

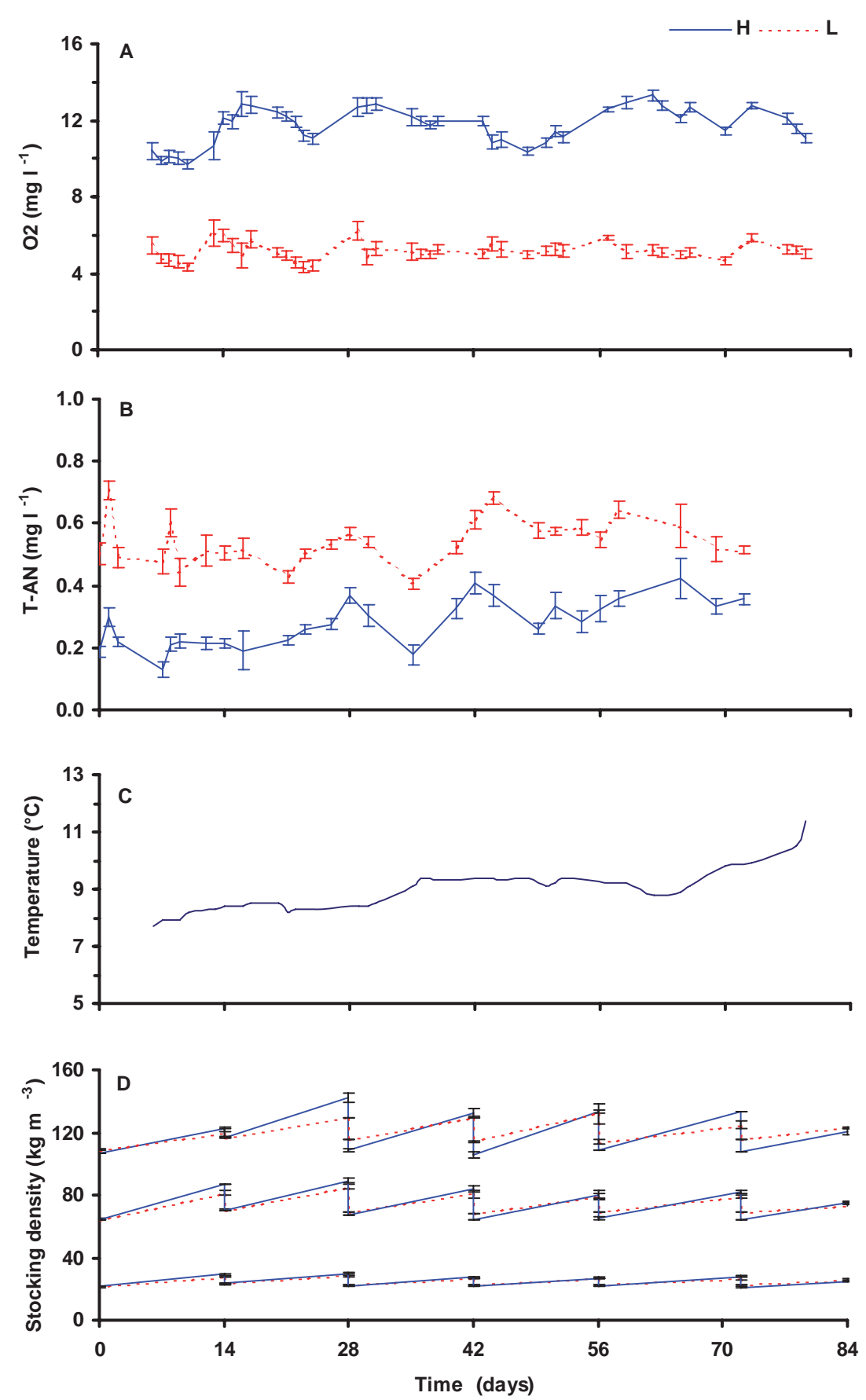

Fig. 1. Changes with time in: ambient oxygen (A), Total Ammonia Nitrogen, T-AN B), temperature (C), and stocking density (D); in relation to water quality: High $(\mathrm{H})$ or Low $(\mathrm{L})$ for rainbow trout rearing. Results are expressed as mean $\pm \mathrm{SE}$.

\subsection{Experimental protocol and sampling}

After the acclimation period, three tanks of each of the stocking density treatments $\left(25,75\right.$ and $\left.120 \mathrm{~kg} \mathrm{~m}^{-3}\right)$ were composed in order to obtain a $3 \times 2 \times 2$ factorial design (stocking density $\times$ water quality $\times$ tank effect). Two different water qualities (Low and High) were assigned randomly to 2 replicates for each density. They were achieved both by using saturated to oversaturated water and adjusting water supply. High water quality $(\mathrm{H})$ was defined by an outlet oxygen concentration of $12 \mathrm{mg} \mathrm{l}^{-1}\left(100 \%\right.$ air saturation at $\left.7^{\circ} \mathrm{C}\right)$ and a total ammonia nitrogen level (T-AN) of $0.3 \mathrm{mg} \mathrm{l}^{-1}$ (the lowest operational T-AN possible under the farm conditions). In low water quality conditions (Low), oxygen concentration was halved $\left(6 \mathrm{mg} \mathrm{l}^{-1} \mathrm{O}_{2}\right)$ and ammonia doubled $\left(0.6 \mathrm{mg} \mathrm{l}^{-1} \mathrm{~T}\right.$-AN, equivalent to $0.002 \mathrm{mg} \mathrm{l}^{-1} \mathrm{NH}_{3}$ at $\mathrm{pH} 7.0$ and $9^{\circ} \mathrm{C}$ ). This lower experimental $\mathrm{O}_{2}$ concentration is around the threshold concentration for growth in Salmonids: $7 \mathrm{mg} \mathrm{l}^{-1} \mathrm{O}_{2}$ (Petersen 1987). The highest ammonia concentration, tested in combination with hypoxia, was just above the concentration recommended 
Table 1. Total mortality, day 0-84 specific growth rate (SGR), feed intake (FI), apparent feed conversion (AFC) and day 84 muscle composition; in relation to water quality $(\mathrm{H}$ and $\mathrm{L})$ and stocking density $\left(25,74,120 \mathrm{~kg} \mathrm{~m}^{-3}\right)$ in rainbow trout.

Means are given with SE $(n=2$ replicates except for fillet composition, $n=4)$. Statistical significance of stocking density $(D)$, water quality $(W)$ and their interaction $(I)$ are indicated $(* p<0.05, * * p<0.01, * * * p<0.001$, NS non significant), and values with different letters indicate treatments that are significantly different.

\begin{tabular}{|c|c|c|c|c|c|c|c|c|c|}
\hline & \multirow[t]{2}{*}{$25-\mathrm{H}$} & \multirow[t]{2}{*}{ 74-H } & \multirow[t]{2}{*}{ 120-H } & \multirow[t]{2}{*}{ 25-L } & \multirow[t]{2}{*}{ 74-L } & \multirow[t]{2}{*}{ 120-L } & \multicolumn{3}{|c|}{ Two-way ANOVA } \\
\hline & & & & & & & D & W & I \\
\hline $\begin{array}{l}\text { Total mortality } \\
(\%)\end{array}$ & $1.3 \pm 0.3^{\mathrm{a}}$ & $0.6 \pm 0.3^{\mathrm{a}}$ & $5.9 \pm 1.3^{\mathrm{a}}$ & $3.0 \pm 1.2^{\mathrm{a}}$ & $1.6 \pm 1.0^{\mathrm{a}}$ & $15.9 \pm 3.6^{b}$ & $* * *$ & $*$ & $*$ \\
\hline $\begin{array}{l}\text { Day 0-84 SGR } \\
\left(\% \text { day }^{-1}\right)\end{array}$ & $1.70 \pm 0.12$ & $1.65 \pm 0.01$ & $1.33 \pm 0.05$ & $1.21 \pm 0.05$ & $1.11 \pm 0.21$ & $1.07 \pm 0.01$ & $*$ & $* * *$ & NS \\
\hline $\begin{array}{l}\text { Day 0-84 FI } \\
(\%)\end{array}$ & $1.46 \pm 0.14$ & $1.49 \pm 0.01$ & $1.51 \pm 0.14$ & $1.07 \pm 0.00$ & $1.05 \pm 0.13$ & $1.01 \pm 0.00$ & NS & $* * *$ & NS \\
\hline Day 0-84 AFC ratio & $0.85 \pm 0.03$ & $0.94 \pm 0.02$ & $1.16 \pm 0.07$ & $0.97 \pm 0.03$ & $1.09 \pm 0.11$ & $1.18 \pm 0.11$ & $* *$ & NS & NS \\
\hline $\begin{array}{l}\text { Day } 84 \text { muscle moisture } \\
\text { (\% wet basis) }\end{array}$ & $68.5 \pm 0.4$ & $69.1 \pm 0.4$ & $70.1 \pm 0.6$ & $71.2 \pm 0.2$ & $71.4 \pm 0.4$ & $72.1 \pm 0.4$ & $*$ & $* * *$ & NS \\
\hline $\begin{array}{l}\text { Day } 84 \text { muscle protein } \\
\text { (\% wet basis) }\end{array}$ & $19.6 \pm 0.4$ & $19.6 \pm 0.2$ & $19.7 \pm 0.3$ & $20.4 \pm 0.4$ & $20.0 \pm 0.2$ & $19.6 \pm 0.2$ & NS & NS & NS \\
\hline $\begin{array}{l}\text { Day } 84 \text { muscle fat } \\
\text { (\% wet basis) }\end{array}$ & $11.0 \pm 0.3$ & $10.8 \pm 0.5$ & $9.4 \pm 0.7$ & $8.0 \pm 0.2$ & $7.5 \pm 0.4$ & $7.4 \pm 0.6$ & NS & $* * *$ & NS \\
\hline $\begin{array}{l}\text { Day } 84 \text { muscle ash } \\
\text { (\% wet basis) }\end{array}$ & $1.5 \pm 0.0$ & $1.5 \pm 0.0$ & $1.6 \pm 0.0$ & $1.6 \pm 0.0$ & $1.6 \pm 0.0$ & $1.7 \pm 0.0$ & $*$ & $* *$ & NS \\
\hline
\end{tabular}

for Salmonid farming: $1 \mathrm{mg} \mathrm{l^{-1 }}$ T-AN (Knoph and Thorud 1996; EPA 1998). The experimental treatments, corresponding to different combinations of SD and water quality conditions, were thus $25-\mathrm{H}, 75-\mathrm{H}$ and $125-\mathrm{H}$ for the high water quality groups and $25-\mathrm{L}, 75-\mathrm{L}$ and $125-\mathrm{L}$ for the low water quality groups.

The experimental unit was supplied with running water at 100 and $300 \% \mathrm{O}_{2}$ air saturation mixed prior use when necessary. Water flow was adjusted according to SD: 12, 36 and $601 \mathrm{~min}^{-1}$ for the $25-\mathrm{H}, 75-\mathrm{H}$ and $125-\mathrm{H}$ groups respectively. These values were reduced to a third for the L groups: 4, 12, and $201 \mathrm{~min}^{-1}$, for $25-\mathrm{L}, 75-\mathrm{L}$ and $125-\mathrm{L}$ respectively, to obtain the chosen combination of $\mathrm{O}_{2}-\mathrm{T}-\mathrm{AN}$ concentrations. Feeding procedure was unchanged from the acclimation to the experimental period, except that the reward level was adjusted to SD so that all fish had to make a similar effort to obtain a similar amount of food. Reward level was 8, 24 and $40 \mathrm{~g}$ per trigger actuation at 25,75 and $120 \mathrm{~kg} \mathrm{~m}^{-3}$ respectively. Each tank was fitted with a sediment trap to collect uneaten pellets. These were weighed twice a week and their dry matter estimated from dried sub samples.

Fish averaged $111.5 \pm 2.4 \mathrm{~g}$ in weight (mean $\pm \mathrm{SE}$ ) at the start of the experiment, which lasted 84 days (February to May). Mortality and water quality parameters were checked daily. Dissolved oxygen concentration was maintained at the two defined levels using computer controlled oxygen inflow (Air Liquid ${ }^{\circledR}$ ). T-AN was measured daily in outlet water using a Tetratest ${ }^{\circledR}$ kit. Water samples were also taken twice a month for $\mathrm{pH}$ measurement (Orion 901 fitted with a Fermbrode electrode ${ }^{\circledR}$ ) and laboratory analysis of T-AN using an automatic colorimetric indophenol method. $\mathrm{NH}_{3}$ concentration versus $\mathrm{T}-\mathrm{AN}$ and $\mathrm{T}^{\circ}$ was thus calculated using the equation of Johansson and Wedborg (1980) as described in Person-Le Ruyet et al. (1997). Flow rate was adjusted when necessary.
At regular intervals fish were sampled for analysis and fasted for $24 \mathrm{~h}$. At days 0,14 and 84, 6 fish per tank (12 fish per experimental condition, 6 fish per tank) were killed with a lethal dose of ethylene glycol-monophenyl ether $\left(2 \mathrm{ml} \mathrm{l}^{-1}\right)$. These fish, removed from the tanks beforehand to avoid the influence of handling stress, were analysed for plasma cortisol. As required, fish blood was taken within less than 6 minutes from the sole tank sampling. At days 7, 14, 28, 56 and 84, 6 fish per tank were taken for other blood analysis and immediately killed with a blow on head. At day 84, the right fillet was taken in 20 fish per experimental group and 4 samples of 5 fish each were stored at $-20{ }^{\circ} \mathrm{C}$ for later analysis on muscle composition.

The fork length and weight were recorded in 60 fish per tank every two weeks and 30 fish were examined for fin damage and other injuries. Prior to measurement, fish were anaesthetized using ethylene glycol-monophenyl ether $\left(0.5 \mathrm{ml} \mathrm{l}^{-1}\right)$. At the same intervals, SD of each tank was estimated by bulk weighing all remaining fish and a calculation was made of the number of fish to remove to stabilize SD near the initial SD for the treatment. Water flow was then adjusted to stabilize water quality parameters.

\subsection{Parameters measured}

Individual fish weight and length were used to calculate specific growth rate (SGR), coefficient of variation for body weight within each tank $(\mathrm{CV})$ and condition factor $(K)$ : SGR $\left(\%\right.$ day $\left.^{-1}\right)=100 \times\left(\ln w_{f}-\ln w_{i}\right)$ day $^{-1}$ where $w_{i}$ and $w_{f}$ are the initial and final mean body weights, respectively.

$\mathrm{CV}(\%)=100 \times$ standard deviation $\times$ mean body weight ${ }^{-1}(\mathrm{~g})$. $K=100 \times$ fish mass $(\mathrm{g}) \times$ fork length ${ }^{-1}\left(\mathrm{~cm}^{3}\right)$.

As some fish were regularly removed from the tanks, daily feed intake (FI) and apparent feed conversion ratio 

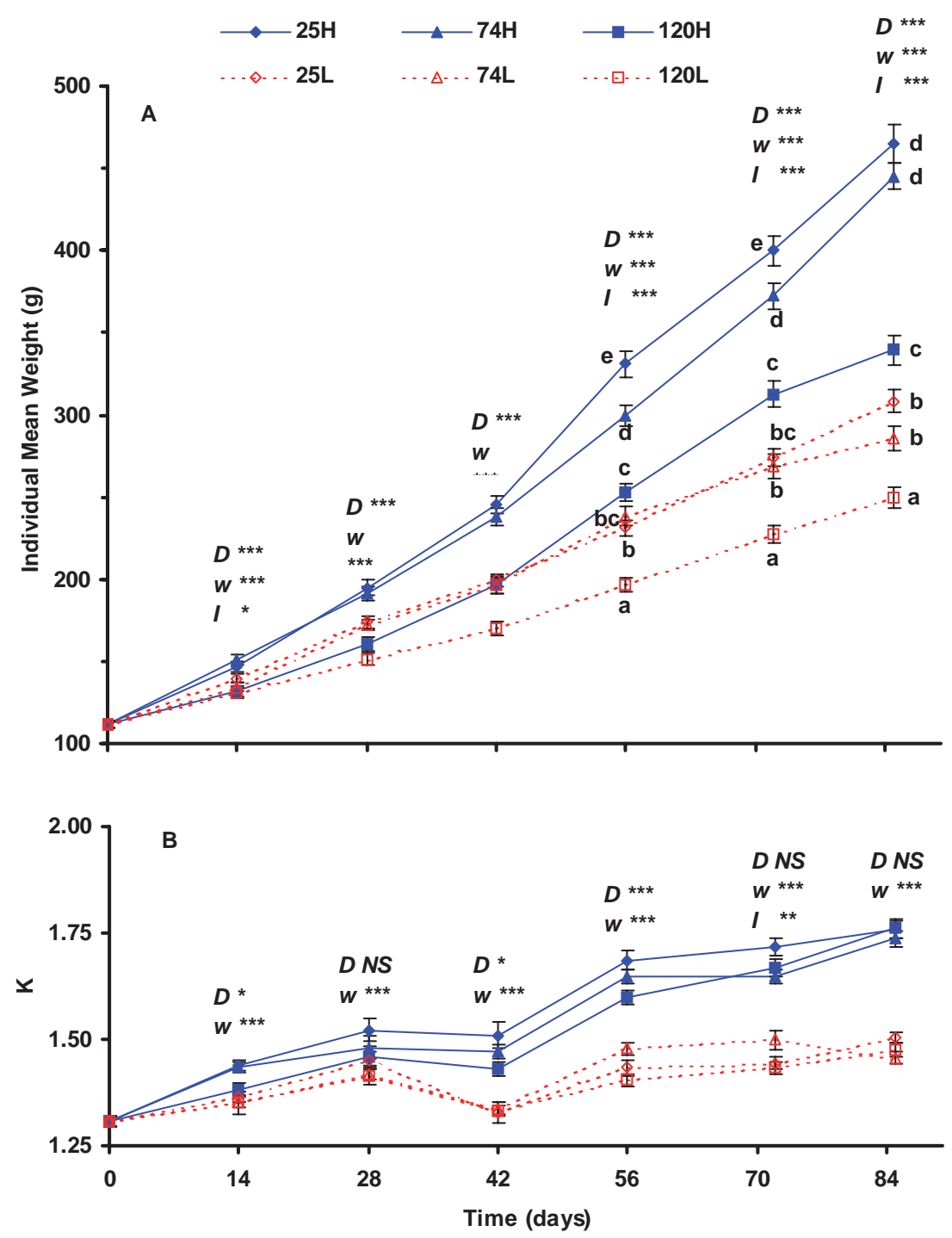

Fig. 2. Weight gain (A) and condition factor, $\mathrm{K}$, (B) over time in relation to water quality ( $\mathrm{H}$ and $\mathrm{L})$ and stocking density $\left(25,74,120 \mathrm{~kg} \mathrm{~m}^{-3}\right)$ in rainbow trout. Results are expressed as mean $\pm \mathrm{SE}(n=60$ per sampling per treatment). Statistical significance of stocking density $(D)$, water quality $(W)$ and their interaction $(I)$ are indicated $(* p<0.05, * * p<0.01, * * * p<0.001$, NS non significant), and values with different letters indicate that treatments were significantly different.

(AFCR) were calculated taking into account the average mass for $t_{1}-t_{2}$ periods (between days $1-7,8-14,15-28,29-42$, 43-54, 55-72 and 73-84) using the following expressions:

FI $(\%)=100 \times($ mean daily mass of dry feed ingested $(\mathrm{g}) \times$ mean wet fish mass ${ }^{-1}(\mathrm{~g})$, where feed ingested $=$ feed distributed less feed collected in the tank trap, mean wet fish mass $=\left(\right.$ fish mass at $t_{2}+$ fish mass at $\left.t_{1}\right) 2^{-1}$ and fish mass $=$ mean body weight $\times$ fish number.

AFCR $=$ dry feed ingested $(\mathrm{g}) \times$ fish mass gain ${ }^{-1}(\mathrm{~g})$

FI and AFCR over the 84-day period were estimated per tank on the basis of the mean value of the 2 -week periods.

Fish fillets were ground and moisture content was determined on homogenate sub-samples $\left(24 \mathrm{~h}\right.$ at $\left.105{ }^{\circ} \mathrm{C}\right)$, the remainder was subsequently freeze-dried and ground before further analyses. Chemical analyses of fish were performed in duplicate for each sample according to AOAC methods (Association of Official Analytical Chemists 1984): ash (7 h at
$550{ }^{\circ} \mathrm{C}$ ), crude fat (Folch method) and crude protein (Dumas method with an Elementary NA 2000ß, $\mathrm{N} \times 6.25$ ).

Fin condition of the dorsal and the two pectoral fins was assessed by relative fin index (RFI) and fin profile as described in Person-Le Ruyet et al. (2004):

RFI $=100 \times$ the highest length of the fin $\times$ fish fork length $^{-1}$.

Fin profile was assessed using a scale of erosion with 5 levels (0-4) referring to the rank of the last intact ray observed for each fin: $0=$ all fin rays intact (a perfect fin) and $4=$ no intact fin rays. The occurrence of other injuries (necrosis, splits, rot) was also noted.

Blood $(1 \mathrm{ml})$ was taken within $1 \mathrm{~min}$ of anaesthesia from caudal vessels and immediately centrifuged (3500 rpm, $5 \mathrm{~min}$ ). Plasma samples for total $\mathrm{CO}_{2}$ concentrations were stored at $4{ }^{\circ} \mathrm{C}$ within $15 \mathrm{~min}$, and measurements made within $6 \mathrm{~h}$ using Sigma Diagnostics enzymatic kit (132-UV). All other 
Table 2. Changes over time in blood plasma ion concentrations in relation to water quality $(\mathrm{H}$ and $\mathrm{L})$ and stocking density $\left(25,74,120 \mathrm{~kg} \mathrm{~m}^{-3}\right)$ in rainbow trout.

Means are given with SE $(n=12)$. Statistical significance of stocking density $(D)$, water quality $(W)$ and their interaction $(I)$ are indicated $\left(* p<0.05, * * p<0.01,{ }^{* * *} p<0.001\right.$, NS non significant) and values with different letters indicate treatments that are significantly different.

\begin{tabular}{|c|c|c|c|c|c|c|c|c|c|c|}
\hline \multirow{2}{*}{\multicolumn{2}{|c|}{ Day }} & \multirow[t]{2}{*}{ 25-H } & \multirow[t]{2}{*}{ 74-H } & \multirow[t]{2}{*}{ 120-H } & \multirow[t]{2}{*}{ 25-L } & \multirow[t]{2}{*}{ 74-L } & \multirow[t]{2}{*}{ 120-L } & \multicolumn{3}{|c|}{ Two-way ANOVA } \\
\hline & & & & & & & & D & $\mathbf{W}$ & I \\
\hline \multirow[t]{6}{*}{ Osmolarity $\left(\mathrm{mmol} \mathrm{1}^{-1}\right)$} & 0 & $311 \pm 2$ & $311 \pm 2$ & $311 \pm 2$ & $311 \pm 2$ & $311 \pm 2$ & $311 \pm 2$ & & & \\
\hline & 7 & $304 \pm 2$ & $306 \pm 1$ & $296 \pm 2$ & $302 \pm 2$ & $303 \pm 1$ & $295 \pm 2$ & $* * *$ & $N S$ & $N S$ \\
\hline & 14 & $303 \pm 1$ & $305 \pm 2$ & $303 \pm 1$ & $302 \pm 1$ & $302 \pm 1$ & $300 \pm 1$ & $N S$ & * & $N S$ \\
\hline & 28 & $305 \pm 1$ & $303 \pm 1$ & $302 \pm 1$ & $299 \pm 1$ & $302 \pm 1$ & $300 \pm 1$ & $N S$ & $* * *$ & $N S$ \\
\hline & 56 & $307 \pm 1$ & $304 \pm 1$ & $305 \pm 1$ & $303 \pm 1$ & $302 \pm 1$ & $302 \pm 1$ & $N S$ & $* *$ & $N S$ \\
\hline & 84 & $311 \pm 2$ & $310 \pm 1$ & $308 \pm 1$ & $303 \pm 1$ & $302 \pm 1$ & $301 \pm 1$ & $N S$ & $* * *$ & $N S$ \\
\hline \multirow[t]{6}{*}{ Sodium $\left(\mathrm{mmol} \mathrm{l}^{-1}\right)$} & 0 & $152.6 \pm 1.22$ & $152.6 \pm 1.2$ & $152.6 \pm 1.2$ & $152.6 \pm 1.2$ & $152.6 \pm 1.2$ & $152.6 \pm 1.2$ & & & \\
\hline & 7 & $143.8 \pm 1.1$ & $145.6 \pm 1.1$ & $143.2 \pm 1.2$ & $146.1 \pm 0.8$ & $145.6 \pm 0.6$ & $141.9 \pm 1.1$ & ** & $N S$ & $N S$ \\
\hline & 14 & $148.7 \pm 1.4$ & $151.3 \pm 0.8$ & $152.7 \pm 0.8$ & $150.3 \pm 1.0$ & $148.9 \pm 0.6$ & $148.8 \pm 1.1$ & $N S$ & $N S$ & $*$ \\
\hline & 28 & $148.1 \pm 0.8$ & $148.1 \pm 1.0$ & $147.1 \pm 0.6$ & $146.0 \pm 1.0$ & $147.4 \pm 0.5$ & $145.5 \pm 0.6$ & $N S$ & $*$ & $N S$ \\
\hline & 56 & $151.1 \pm 0.4$ & $150.5 \pm 0.6$ & $152.9 \pm 1.2$ & $148.9 \pm 0.4$ & $148.8 \pm 0.6$ & $148.8 \pm 0.7$ & $N S$ & $* * *$ & $N S$ \\
\hline & 84 & $151.2 \pm 0.7$ & $152.2 \pm 1.1$ & $152.6 \pm 0.8$ & $148.9 \pm 0.8$ & $148.4 \pm 0.8$ & $147.1 \pm 0.6$ & $N S$ & $* * *$ & $N S$ \\
\hline \multirow[t]{6}{*}{ Chloride (mmol 1-1) } & 0 & $125.6 \pm 0.7$ & $125.6 \pm 0.7$ & $125.6 \pm 0.7$ & $125.6 \pm 0.7$ & $125.6 \pm 0.7$ & $125.6 \pm 0.7$ & & & \\
\hline & 7 & $120.6 \pm 0.7$ & $119.2 \pm 0.7$ & $118.9 \pm 1.1$ & $120.1 \pm 0.7$ & $119.3 \pm 0.7$ & $115.3 \pm 0.9$ & $* * *$ & $N S$ & $N S$ \\
\hline & 14 & $122.1 \pm 1.0$ & $122.5 \pm 0.7$ & $123.2 \pm 0.6$ & $120.7 \pm 0.9$ & $121.9 \pm 0.9$ & $123.1 \pm 1.1$ & $N S$ & $N S$ & $N S$ \\
\hline & 28 & $120.5 \pm 0.6$ & $120.4 \pm 0.8$ & $120.1 \pm 0.6$ & $118.6 \pm 0.8$ & $122.0 \pm 0.8$ & $121.1 \pm 0.8$ & $N S$ & $N S$ & $N S$ \\
\hline & 56 & $120.7 \pm 0.8$ & $122.0 \pm 0.4$ & $120.9 \pm 0.6$ & $119.8 \pm 0.8$ & $120.2 \pm 0.6$ & $121.8 \pm 1.1$ & $N S$ & $N S$ & $N S$ \\
\hline & 84 & $121.3 \pm 0.6$ & $124.0 \pm 1.3$ & $121.5 \pm 1.0$ & $120.8 \pm 1.0$ & $119.8 \pm 0.7$ & $121.7 \pm 0.8$ & $N S$ & $N S$ & $*$ \\
\hline \multirow[t]{6}{*}{ Total $\mathrm{CO}_{2}\left(\mathrm{mmol} \mathrm{l}^{-1}\right)$} & 0 & $7.4 \pm 0.3$ & $7.4 \pm 0.3$ & $7.4 \pm 0.3$ & $7.4 \pm 0.3$ & $7.4 \pm 0.3$ & $7.4 \pm 0.3$ & & & \\
\hline & 7 & $10.3 \pm 0.4$ & $10.8 \pm 0.5$ & $9.1 \pm 0.4$ & $10.2 \pm 0.2$ & $11.2 \pm 0.3$ & $10.2 \pm 0.4$ & $* *$ & $N S$ & $N S$ \\
\hline & 14 & $10.2 \pm 0.4$ & $11.2 \pm 0.2$ & $10.1 \pm 0.2$ & $10.1 \pm 0.3$ & $10.5 \pm 0.4$ & $10.2 \pm 0.4$ & $* *$ & $*$ & $N S$ \\
\hline & 28 & $14.2 \pm 0.5$ & $13.4 \pm 0.5$ & $12.3 \pm 0.4$ & $11.6 \pm 0.5$ & $11.3 \pm 0.6$ & $10.2 \pm 0.4$ & $* * *$ & $* * *$ & $N S$ \\
\hline & 56 & $12.5 \pm 0.5$ & $10.9 \pm 0.4$ & $10.6 \pm 0.5$ & $9.7 \pm 0.4$ & $9.2 \pm 0.5$ & $10.2 \pm 0.4$ & $*$ & $* * *$ & $N S$ \\
\hline & 84 & $12.1 \pm 0.5$ & $10.5 \pm 0.6$ & $12.3 \pm 0.4$ & $9.5 \pm 0.5$ & $9.5 \pm 0.6$ & $10.2 \pm 0.4$ & $N S$ & $* * *$ & $N S$ \\
\hline
\end{tabular}

Table 3. Changes over time in blood plasma hormone concentrations and haematological parameters in relation to water quality (H and L) and stocking density $\left(25,74,120 \mathrm{~kg} \mathrm{~m}^{-3}\right)$ in rainbow trout. Means are given with $\mathrm{SE}(n=12)$. Statistical significance of stocking density $(D)$, water quality $(W)$ and their interaction $(I)$ are indicated $(* p<0.05, * * p<0.01, * * * p<0.001$ and NS non significant), and values with different letters indicate that treatments are significantly different.

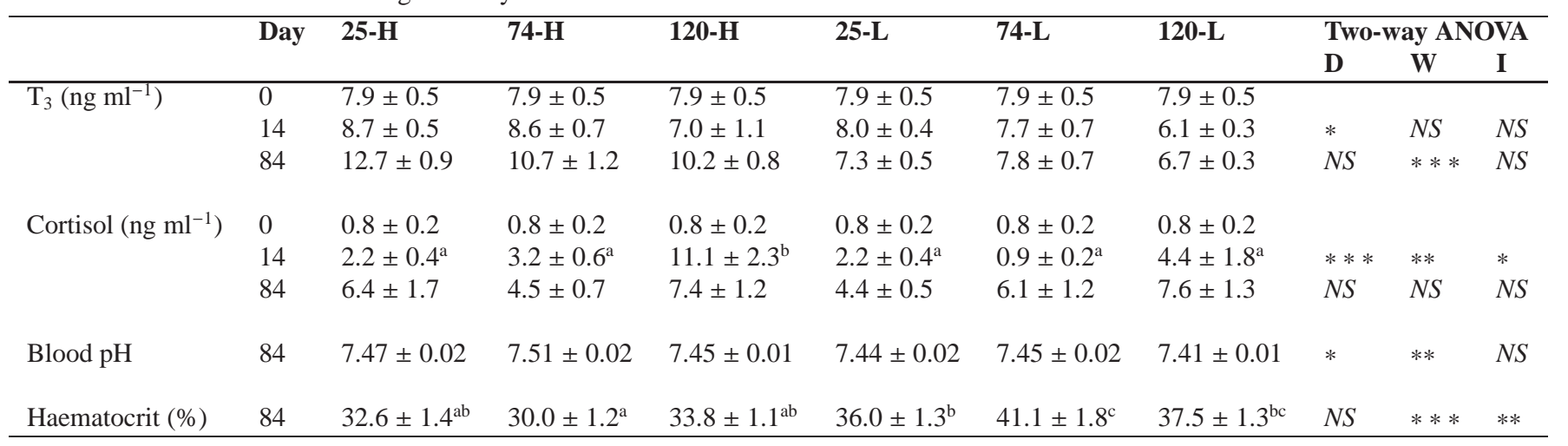

blood analyses were performed on plasma samples that had been stored frozen at $-20{ }^{\circ} \mathrm{C}$ : osmolarity was measured using an Advanced Instrument Osmometer ${ }^{\circledR}$, chloride by argentimetric titration using a Radiometer CMT10 ${ }^{\circledR}$, sodium and potassium using an Electrolyte Beckman Analyser ${ }^{\circledR}$, and glycemia using Sigma Diagnostics enzymatic kits (HK 10). Plasma cortisol and tri-iodothyronine concentrations were measured by specific radio-immunoassays (Fostier et al. 1982;
Boeuf et al. 1989). At day 84, assessments were made of haematocrit (10000 rpm, $5 \mathrm{~min}$ ) and blood pH (Metrohm ${ }^{\circledR}$ $\mathrm{pH}$ meter fitted with a microflow $\mathrm{pH}$ sensor).

\subsection{Statistical analysis}

Statistical analyses were performed using Statistica ${ }^{\circledR}$ for Windows, and all results expressed as mean \pm SE. For each 

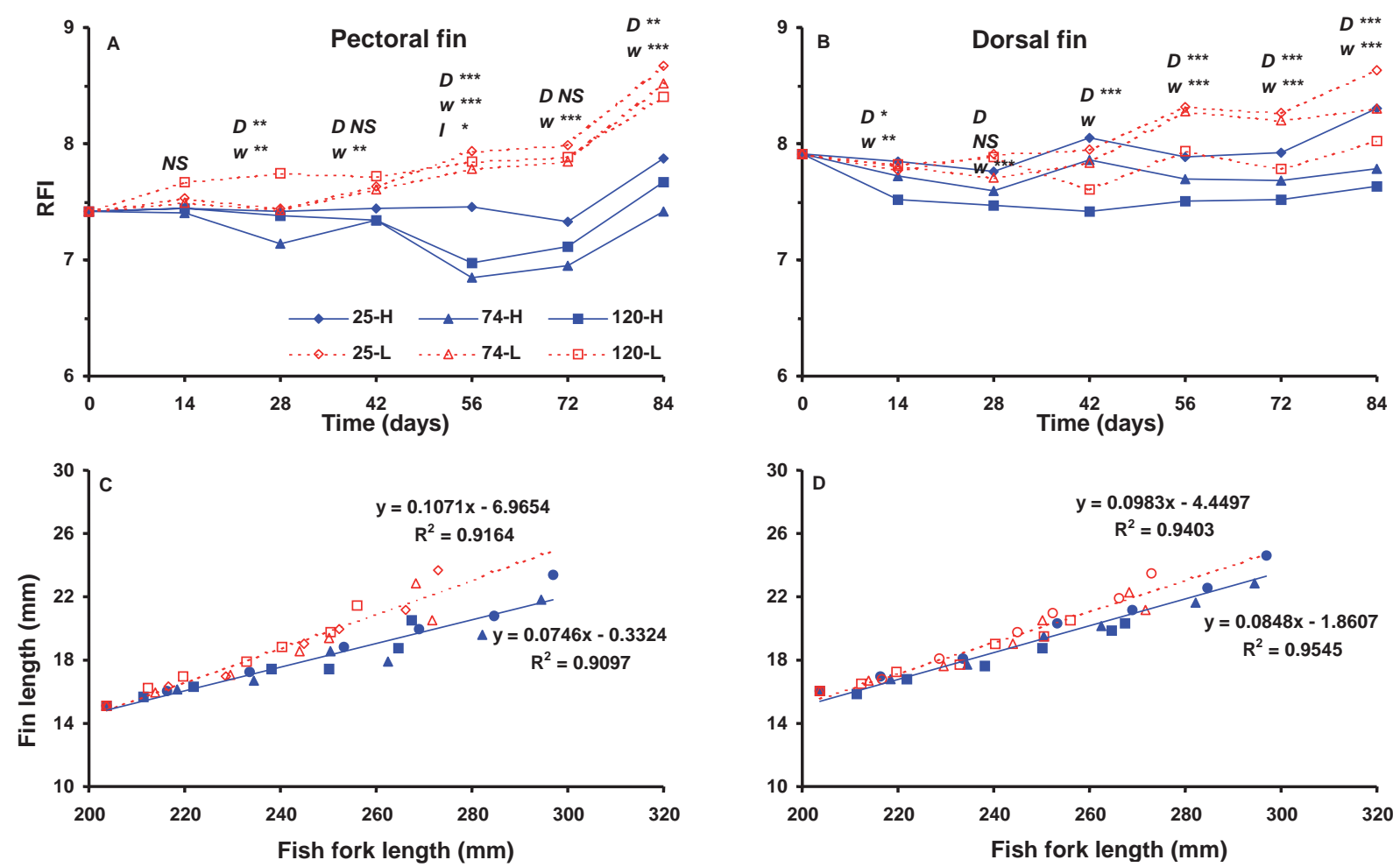

Fig. 3. Relative length index of left pectoral (A) and dorsal (B) fins over time, and respective fin length to fish length relationships (C and D); in relation to water quality $(\mathrm{H}$ and $\mathrm{L})$ and stocking density $\left(25,74,120 \mathrm{~kg} \mathrm{~m}^{-3}\right)$ in rainbow trout $(n=30$ per sampling per treatment). Statistical significance of stocking density $(D)$, water quality $(W)$ and their interaction $(I)$ are indicated $(* p<0.05, * * p<0.01$, *** $p<0.001$, NS non significant). Regression equations are given for the 2 water quality groups with $y=$ mean fin length and $x=$ mean fish fork length $(n=18)$.

parameter, differences between the 6 experimental conditions with time were tested by a two way ANOVA to identify the effects of water quality, SD and their potential interaction. Prior to ANOVA analysis, data expressed in \% were arcsin square-root transformed. When significant interactions were observed, differences between means were compared using a Newman-Keuls test, differences were considered significant at $P<0.05$.

\section{Results}

Differences in environmental parameters between the 2 water quality groups $(\mathrm{H}$ and $\mathrm{L})$ and the 3 stocking densities (SDs) were stable throughout the experiment (Fig. 1). Mean SDs $( \pm$ SE, $n=24)$ were $24.83 \pm 0.17 ; 74.24 \pm 0.55$ and $120.04 \pm 0.88 \mathrm{~kg} \mathrm{~m}^{-3}$ in the 3 experimental SD groups, and temperature increased progressively from 8 to $11{ }^{\circ} \mathrm{C}$. Water quality parameters were similar in the $3 \mathrm{SD}$ groups, apart from minor differences in $\mathrm{pH}$ ( $\mathrm{pH}$ differences between 25 and $120 \mathrm{~kg} \mathrm{~m}^{-3}$ were 0.02 and 0.1 in $\mathrm{L}$ and $\mathrm{H}$ groups respectively). In the $\mathrm{H}$ group, ambient $\mathrm{O}_{2}$ was $11.71 \pm 0.15 \mathrm{mg} \mathrm{l}^{-1}$, T-AN $0.28 \pm 0.01 \mathrm{mg} \mathrm{l}^{-1}$ and $\mathrm{pH}, 6.22 \pm 0.01$; and in the $\mathrm{L}$ group, $\mathrm{O}_{2}$ was $5.15 \pm 0.07 \mathrm{mg} \mathrm{l}^{-1}$, T-AN $0.54 \pm 0.01 \mathrm{mg} \mathrm{l}^{-1}$ and $\mathrm{pH} 5.96 \pm 0.01$. Calculated $\mathrm{NH}_{3}-\mathrm{N}$ concentrations were low and similar between $\mathrm{H}$ and $\mathrm{L}$ groups: $8.1 \times 10^{-5} \mathrm{mg}^{-1}$ and $8.4 \mathrm{mg}^{-1}$ respectively. For comparison, the initial water inflow parameters were: T-AN, $0.053 \pm 0.006 \mathrm{mg} \mathrm{l}^{-1} ; \mathrm{pH}$ $6.56 \pm 0.006$ and $\mathrm{NH}_{3}-\mathrm{N}, 3.3 \times 10^{-5} \mathrm{mg} \mathrm{l}^{-1}$.
No disease or skin injuries were detected. Mortality rate was affected by SD and to a lesser extent by water quality. It was $16 \%$ and $6 \%$ in $120-\mathrm{L}$ and $120-\mathrm{H}$ groups, for unclear reasons. In all other rearing conditions mortality was low, 1$1.5 \%$ (Table 1 ).

Mass increase was highly affected by SD and water quality with frequent significant interactions (Fig. 2). The best growth results were always observed in $\mathrm{H}$ water and the lowest at $120 \mathrm{~kg} \mathrm{~m}^{-3}$. Differences in final weight between $25 \mathrm{~kg} \mathrm{~m}^{-3}$ and $120 \mathrm{~kg} \mathrm{~m}^{-3}$ were $27 \%$ in $\mathrm{H}$ and $19 \%$ in L. There was no significant difference between 25 and $74 \mathrm{~kg} \mathrm{~m}^{-3}$ in the $\mathrm{L}$ water quality group during the course of the experiment, or at the end of the experiment in $\mathrm{H}$ water quality group. In the $\mathrm{H}$ group though, a significantly lower weight (9-7\%) was observed at $74 \mathrm{~kg} \mathrm{~m}^{-3}$ compared with $25 \mathrm{~kg} \mathrm{~m}^{-3}$ at days 54 and 72 . There was no change in fish weight dispersion related to experimental conditions, weight CV was $17.3 \%$ at day 0 and $25-27 \%$ at day $84\left(120-25 \mathrm{~kg} \mathrm{~m}^{-3}\right)$.

SGR values for the day $0-84$ period confirmed that water quality had a higher effect on growth than did SD, $p=0.0004$ and $p=0.032$ respectively (Table 1 ). Differences in growth between the two water quality groups can partly be explained by differences in feed intake: FI for the same period was $1.5 \%$ of fish mass in $\mathrm{H}$ groups compared with 1.1-1.0 in L groups. When the reward delivered per triggering actuation was fitted to SD, feed intake was not significantly affected by SD. Conversely apparent feed conversion ratio (AFC) was impaired, it increased as SD increased. AFC was similar in the two water quality groups at $120 \mathrm{~kg} \mathrm{~m}^{-3}(1.2)$, but significantly higher 


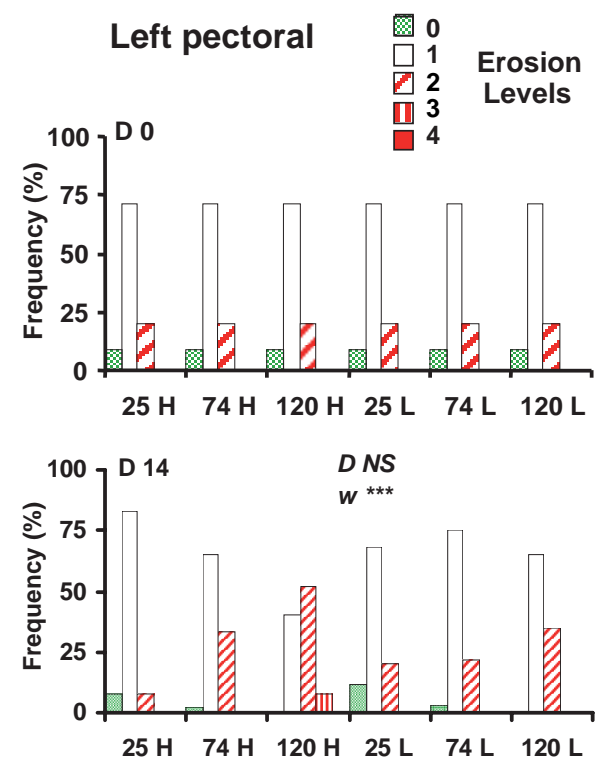

Dorsal fin
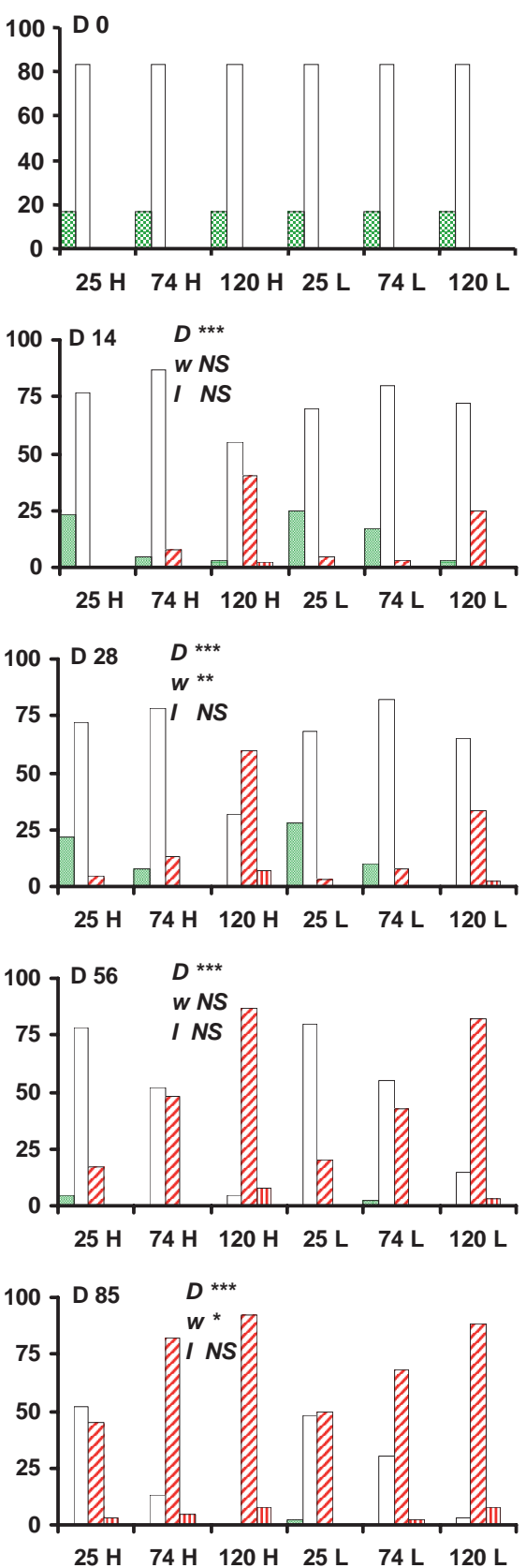

Fig. 4. Frequency of erosion levels in left pectoral and dorsal fins in relation to water quality $(\mathrm{H}$ and $\mathrm{L})$ and stocking density $\left(25,74,120 \mathrm{~kg} \mathrm{~m}^{-3}\right)$ in rainbow trout $(n=30$ per sampling per treatment). Statistical significance of stocking density $(D)$, water quality $(W)$ and their interaction $(I)$ between erosion levels $0-1$ and erosion levels $2-4$ are indicated $(* p<0.05, * * p<0.01, * * * p<0.001$, NS non significant).

than at 25 and $74 \mathrm{~kg} \mathrm{~m}^{-3},(0.8-0.9$ and $1.0-1.1$ respectively in $\mathrm{H}$ and L: no significant (NS) differences between water quality groups).

Changes in fish morphology with time were observed in relation to water quality (Fig. 2). In the L group, condition factor, $\mathrm{K}$, was stable around 1.3-1.4 and in the H group it progressively increased from 1.4-1.5 to 1.7 (NS with SD from day 72 ). At the end of the experiment, fillet total lipid content was the highest in $\mathrm{H}$ water quality groups (NS with SD) when FI was the highest and marked differences in fish morphology were observed. Fillet protein content was not significantly affected by SD or by water quality (Table 1).

Some changes in fish physiological status over time were related to water quality and $\mathrm{SD}$, but there were almost no interactions (Tables 2 and 3). The disturbances in plasma osmolarity and $\mathrm{Na}^{+}$and $\mathrm{Cl}^{-}$contents were initially related to $\mathrm{SD}$ 
(significant differences at day 7 only) and then, from day 14, related to water quality (significant differences in osmolarity and $\mathrm{Na}^{+}$observed up to the end of the experiment). Plasma total $\mathrm{CO}_{2}$ concentrations were affected both by SD and water quality: they were lower at $120 \mathrm{~kg} \mathrm{~m}^{-3}$ than at 25 and $74 \mathrm{~kg}$ $\mathrm{m}^{-3}$ up to day 84 and were more frequently lower in $\mathrm{L}$ than in $\mathrm{H}$ water quality groups. There were no signs of acute stress in any groups except at day 14 when plasma cortisol contents were significantly higher in the $120-\mathrm{H}$ treatment (significant SD and water quality effects). At day 84 there were NS differences in plasma cortisol between the experimental conditions tested. The other physiological indicators measured (plasma $\mathrm{T}_{3}$, blood $\mathrm{pH}$ and haematocrit) showed that fish condition was more affected by water quality than by SD (NS with SD at the end of the experiment).

Dorsal and pectoral fin characteristics were affected both by experimental conditions and experiment duration. There were no cases of necrosis, bleeding extremities or splits longer than $10 \%$ of fin length in either fin. A similar response to the experimental conditions was observed for right and left pectoral fins. From day 28, pectoral relative fin index RFI was highly affected by water quality, being highest in the L group, and there were no clear effects of SD (Fig. 3A). Dorsal RFI was significantly affected by water quality from day 14 and by SD from day 42, but there was no interaction between water quality and SD (Fig. 3B). Fin length to fish fork length relationships, illustrated in Fig. 3C for pectoral and in Fig. 3D for dorsal fins, showed that fin length was dependent on fish size and rearing conditions: for a given fish size, the longest fins were observed in the $\mathrm{L}$ groups. Fin profile was also affected by water quality and SD, and marked changes were observed with time (Fig. 4). Mean erosion level of pectoral fins increased from 1.1 at day $0\left(70 \%\right.$ level 1) to 1.7 at $25 \mathrm{~kg} \mathrm{~m}^{-3}$ and 2.1 at $74-120 \mathrm{~kg} \mathrm{~m}^{-3}$ in the $\mathrm{H}$ water group at day $84(80 \%$ level 2). Pectoral profile was affected less in the $\mathrm{L}$ than in $\mathrm{H}$ water groups (mean erosion level, 1.5 at $25 \mathrm{~kg} \mathrm{~m}^{-3}$ and $1.8-$ 1.9 at $74-120 \mathrm{~kg} \mathrm{~m}^{-3}$ ). The erosion of dorsal fin increased with time and SD, though there was no clear effect of water quality.

\section{Discussion}

No disease or technical problems occurred during the course of the experiment so we can consider that water quality and SD effects were correctly assessed. There was no deterioration of water quality due to SD itself, as water flow was adjusted to the chosen SD levels. The minor differences in $\mathrm{pH}$ observed between 25 and $120 \mathrm{~kg} \mathrm{~m}^{-3}$ may have resulted from possible differences in $\mathrm{CO}_{2}$ concentrations (not measured). The lower $\mathrm{pH}$ in the low (L) water quality group (5.96), compared with the high $(\mathrm{H})$ water quality group (6.22), was mainly the result of the lower water exchanges used to obtain the desired oxygen-ammonia combination in the L group. In all experimental conditions though, ambient $\mathrm{pH}$ was similar to the $\mathrm{pH}$ of the inflow water (6.56) and in the safe range for Salmonids (Fivelstad et al. 2004).

Under the conditions of this study, which included ondemand feeding, $120 \mathrm{~kg} \mathrm{~m}^{-3}$ was inappropriate for maximum growth irrespective of water quality: weight was 30 to $20 \%$ lower at $120 \mathrm{~kg} \mathrm{~m}^{-3}$ compared with $25 \mathrm{~kg} \mathrm{~m}^{-3}$. The highest
SD did not correspond to the best survival either in $\mathrm{L}$ water. In $\mathrm{H}$ water, it was possible to grow trout at $74 \mathrm{~kg} \mathrm{~m}^{-3}$ without affecting growth, which agrees with results by North et al. (2006a). Conversely, when water quality was lower, growth was depressed in all SD groups. The most important factor involved in the growth limitation in L water was probably oxygen, as this was below the threshold concentration for growth, $7 \mathrm{mg} \mathrm{l}^{-1} \mathrm{O}_{2}$ (Petersen 1987). Despite low un-ionized ammonia concentrations, a depressive effect of ammonia cannot be excluded, as ammonia toxicity is higher under hypoxic conditions (Thurston et al. 1981; EPA 1998). The low weight dispersion in all groups over the course of the experiment could be explained by specific conditions of this study: fish were fed on demand using a reward proportional to SD and environmental conditions were maintained stable. Food access (feeding schedule, ration per meal or per trigger actuation) and environmental conditions (water quality, SD) are factors that may increase social interactions leading to size heterogeneity or physical damage (Jobling 1994; Boujard et al. 2002; Turnbull et al. 2005; Noble et al. 2007).

Feeding conditions and especially food access are often responsible for the observed effects of SD under experimental and farm conditions (Holm et al. 1990; Ellis et al. 2002; Boujard et al. 2002). In this study there was no food shortage and feed efficiency was high up to $75 \mathrm{~kg} \mathrm{~m}^{-3}$ in the two water quality groups. At $120 \mathrm{~kg} \mathrm{~m}^{-3}$, fish seemed less efficient in utilizing ingested feed, but it is possible that an overestimation of feed intake was made as feed losses were not collected every day at the experimental farm. The physical changes in fish of the $\mathrm{H}$ water group compared to L group, as represented by the high condition factor, indicate an adverse effect of this water on fish welfare. When using demand feeders and a high reward per trigger actuation, there is a risk of excessive feeding especially in strains selected for maximum growth, mainly explained by a feed intake stimulation (Mambrini et al. 2004). In the present study, fish in the $\mathrm{H}$ group should have been food restricted for better welfare and also to reduce fillet fat content. Fish condition factor was not affected by SD, which is in agreement with other results showing that rainbow trout can sustain fast growth at relatively high SD under certain conditions (Boujard et al. 2002; North et al. 2006a, this study). Rainbow trout selected for low responsiveness to stress could be better adapted to high SD than non-selected fish, so a strategy of selection could be used to improve fish growth under intensive conditions (Trenzado et al. 2006).

Physiological measures showed that fish were more affected by water quality than by SD. The decrease in water quality may have durably affected ion exchanges, as shown by the lower osmolarity and $\mathrm{Na}^{+}$content, and a new equilibrium quickly reached. The moderate decrease in plasma $\mathrm{CO}_{2}$ in $\mathrm{L}$ water with high SD indicated some disturbances in acid base balance resulting from respiratory adjustments. These adaptive mechanisms are stimulated under any stressful environmental conditions where fish require extra energy to adapt (Brett and Groves 1979; Maxime et al. 2000). The relative increase in plasma cortisol measured on day 14 at $120 \mathrm{~kg} \mathrm{~m}^{-3}$ only, may suggest that fish were recovering from an initial stress from the sharp increase of SD at day 0 and shown by the marked changes in all physiological measures at day 7. It would also 
have been interesting to measure plasma cortisol in the first days of the experiment or during crowding when fish were feeding. At day 84 there was no sign of acute stress or anaemia in any of the groups. Physiological measures were within their normal ranges, indicating that the rainbow trout had become acclimated to SD as high as $120 \mathrm{~kg} \mathrm{~m}^{-3}$ even in $\mathrm{L}$ water. There is extensive literature on stress and fish recovery in response to acute stresses (crowding for example), but there is a lack of evidence that SD itself increases disease incidence or chronic stress in Salmonids (Barton 2002; Ellis et al. 2002). In rainbow trout held under high SD, no changes in plasma cortisol related to SD have generally been observed beyond the adaptation period in past studies (Vijayan et al. 1990; Procarione et al. 1999), which is in agreement with our results. However, elevated plasma cortisol can be observed at low SD. For example North et al. (2006a) reported that plasma cortisol can be higher at 10 than at $40-80 \mathrm{~kg} \mathrm{~m}^{-3}$, but could not be explained by SD itself. This result was possibly due to a higher response to additional handling stress. However a similar response may be induced by a direct or visual contact with a predator, as evidenced in zebrafish by Barcellos et al. (2007).

This study also showed that pectoral and dorsal fin condition was high in all groups: no fin loss, no obvious functional abnormality (no level 4 damage was observed) and no other severe damage (bite marks, tissue deterioration with haemorrhagic or inflamed extremities). The fins examined were longer and abrasion of external fin rays was lower at the lowest SD and in the $\mathrm{L}$ water quality, i.e. in fish with low metabolic activity and a large amount of space, but in sub-optimal water quality. SD effect could be due to a severe reduction in space when $\mathrm{SD}$ is high and to crowding and accidental damage caused during feeding. The effects of water quality appear to be counterintuitive, but may be explained by the marked differences in feeding activity in the L water quality treatment, considering that overcrowding when feeding can lead to fin abrasion due to direct contact between the fish as reported in different welfare reviews (Ellis et al. 2002; Huntingford et al. 2006). Differences in water velocity between the two water quality groups (for technical reasons) may also have induced some differences in fin erosion, as commonly reported in young stages (Pelis and McCormick 2003). The overall pattern of increasing fin abrasion with time was similar for pectoral and dorsal fins, indicating common causes such as handling, swimming activity, feeding, or contact with the rearing tank walls. Under any rearing condition caudal damage is frequent in small and large rainbow trout as a result it is a less efficient means of studying the effects of environmental factors than pectoral and dorsal fin condition (Latremouille 2003). Conversely caudal condition is a relevant indicator prior commercialisation in current use by farmers (Roque, pers. comm.). Pectoral fin condition seems relevant for testing SD or water velocity effects and dorsal fin condition for testing hierarchy strength (Moutou 1998; Latremouille 2003). This study showed that fin profile is a preferable measurement to relative fin length index, as observed differences in fin length may result both from differences in fish size and rearing conditions. The difficulties of using solely fin damage as a welfare descriptor have been discussed in several studies (Turnbull et al. 2005; Noble et al. 2006b; Hoyle et al. 2007).
To conclude, this study provides scientific information on the combined effects of water quality (achieved by water flow and oxygen concentration) and SD on growth and welfare of rainbow trout that may be useful to legislators dealing with protection measures for farmed fish. Our work highlights the importance of water quality when considering SD effects and showed that $120 \mathrm{~kg} \mathrm{~m}^{-3}$ was inappropriate for maximum growth performances irrespective of water quality, even though there were no major physiological disturbances, signs of suffering or major fin damage compromising fish health and welfare. It also showed that a combination of high water quality and excessive feeding impaired the aesthetic appearance of fish, which is considered as an important welfare indicator. This demonstrates that a guideline to define good and bad welfare is needed that uses a multivariable analysis based on relevant growth, physical and physiological indicators.

Acknowledgements. This study was part of a national contract (01/2 210488 , DGAL-Inra-Ifremer). The authors are grateful to the staff of Sizun and to colleagues from IFREMER Brest, for help and advice.

\section{References}

Anonymous, Farm Animal Welfare Council, 1996, Report on the welfare of farmed fish. FAWC, Surbiton, Surrey., $13 \mathrm{p}$.

AOAC (Association of Official Analytical Chemists), 1984, Official methods of analysis of the Association of Analytical Chemists, S. Williams ed. Arlington, VA.

Ashley P.J., 2007, Fish welfare: current issues in aquaculture. Appl. Anim. Behav. Sci. 104, 199-235.

Barton B.A., 2002, Stress in fish: a diversity of responses with particular reference to changes in corticosteroids. Integ. Comp. Biol. 42, 517-525.

Barcellos L.J.G., Ritter F., Kreutz L.C., Quevedo R.M., Da Silva L.B., Bedin A.C., Finco J., Cericato L., 2007, Whole body cortisol increases after direct and visual contact with a predator in zebrafish, Danio rerio. Aquaculture 272, 774-778.

Bégout-Anras M.L., Lagardère J.P., 2004, Measuring cultured fish swimming behaviour: first results on rainbow trout using acoustic telemetry in tanks. Aquaculture 240, 175-186.

Boeuf G., Le Bail P.Y., Prunet P., 1989, Growth hormone and thyroid hormones during Atlantic salmon Salmo salar L., smoltification and after transfer to seawater. Aquaculture 82, 257-268.

Boujard T., Labbé L., Aupérin B., 2002, Feeding behaviour, energy expenditure and growth of rainbow trout in relation to stocking density and food accessibility. Aquac. Res. 33, 1233-1242.

Brett J.R., 1979, Environmental factors and growth. In: Hoar W.S., Randall D.J., Brett J.R. (Eds.), Bioenergetics and growth. Fish Physiology, vol.VIII, Academic Press, New York, pp. 599-675.

Brett J.R., Groves T.D.D., 1979, Physiological energetics. In: Hoar, W.S., Randall, D.J., Brett J.R. (Eds.), Bioenergetics and growth. Fish Physiology, vol. VIII, Academic Press, New York, pp. 279352.

Conte F.S., 2004, Stress and the welfare of cultured fish. Appl. Anim. Behav. Sci. 86, 205-223.

Ellis T., North, B.P., Scott A.P., Bromage N.R., Porter M.J., Gadd D., 2002, The relationships between stocking density and welfare in farmed rainbow trout. J. Fish Biol. 61, 493-531. 
EPA, 1998, Update of ambient water quality criteria for ammonia. EPA 822-R-98-008, Washington, United States Environmental Protection Agency.

Fivelstad S., Bergheim A., Holland P.M., Fjermedal A.B., 2004, Water flow requirements in the intensive production of Atlantic salmon (Salmo salar L.) parr-smolt at two salinity levels. Aquaculture 231, 263-277.

Fostier A., Billard R., Breton B., Legendre M., Marlot S., 1982, Plasma 11-exotestosterone and gonadotropin during the beginning of spermiation in rainbow trout (Salmo gairdneri R.). Gen. Comp. Endocrinol. 46, 428-434.

Geode R.W., Barton B.A., 1990, Organismic indices and an autopsybased assessment as indicators of health and condition of fish. Am. Fish. Soc. Symp. 8, 93-108.

Gornati R., Papis E., Rimoldi S., Terova G., Saroglia M., Bernadini G., 2004, Rearing density influences the expression of stressrelated genes in sea bas (Dicentrarchus labrax L.) Gene 1, 111118.

Holm J.C., Refstie T., Sigbjorn B., 1990, The effect of fish density and feeding regimes on the individual growth rate and mortality in rainbow trout (Oncorhynchus mykiss). Aquaculture 89, 225232.

Hoyle I., Oidtmann B., Ellis T., Turnbull J., North B., Nikolaidis J, Knowles T.G., 2007, A validated macroscopic key to assess fin damage in farmed rainbow trout (Oncorhynchus mykiss). Aquaculture 207, 142-148.

Huntingford F.A., Adams C.E., Braithwaite V.A., Kadri S., Pottinger T.G., Sandoe P., Turnbull J.F., 2006, Current issues in fish welfare. J. Fish Biol. 68, 332-372.

Johansson O., Wedborg W., 1980, The ammonia-ammonium equilibrium in sea water at temperature between 5 and $25^{\circ} \mathrm{C}$. J. Solut. Chem. 91, 37-44.

Jobling M., 1994, Fish bioenergetics. Chapman \& Hall, London.

Knoph M.B., Thorud K., 1996, Toxicity of ammonia to Atlantic salmon (Salmo salar) in sea water. Effects on plasma osmolality, ion, ammonia, urea and glucose levels and haematologic parameters. Comp. Biochem. Physiol. 113A, 375-381.

Latremouille D.N., 2003, Fin erosion in aquaculture and natural environments. Rev. Fish. Sci. 11, 315-335.

Lefrançois C., Claireaux G., Mercier C., Aubin J., 2001, Effect of density on the routine metabolic expenditure of farmed rainbow trout (Onchorhynchus mykiss). Aquaculture 195, 269-277.

Lemarié G., Dosdat A., Coves D., Dutto G., Gasset E., Person-Le Ruyet J., 2004, Effect of chronic ammonia exposure on growth of European seabass (Dicentrarchus labrax) juveniles. Aquaculture 229, 479-491.

Mambrini M., Sanchez M.P., Chevassus B., Labbé L., Quillet E., Boujard T., 2004, Selection for growth increases feed intake and affects feeding behavior of brown trout. Livestock Prod. Sci. 88, 85-98.

Maxime V., Pichavant K., Boeuf G., Nonnotte G., 2000, Effects of hypoxia on respiratory physiology of turbot, Psetta maxima. J. Fish Biol. 22, 51-59.

Montero D., Izquierdo M.S., Tort L., Robaina L., Vergara J.M., 1999, High stocking density produces crowding stress altering some physiological and biochemical parameters in gilthead seabream, Sparus aurata, juveniles. Fish Physiol. Biochem. 20, 53-60.

Moutou K. A., McCarthy I.D., Houlihan D.F., 1998, The effect of ration level and social rank on the development of fin damage in juvenile rainbow trout. J. Fish Biol. 52, 756-770.
North B.P., Turnbull J.F., Ellis T., Porter M.J., Migaud H., Bron J., Bromage N.R., 2006a, The impact of stocking density on the welfare of rainbow trout (Oncorhynchus mykiss). Aquaculture 255, 466-479.

North B.P., Ellis T., Davis J., Bromage N.R., 2006b, Stocking density practices of commercial UK rainbow trout farms. Aquaculture 259, 260-267.

Noble C., Mizusawa K., Suzuki K., Tabata M., 2007, The effect of differing self-feeding regimes on the growth, behaviour and fin damage of rainbow trout held in groups. Aquaculture 264, 214 222.

Pelis R.M., McCormick S.D., 2003, Fin development in stream- and hatchery-reared Atlantic Salmon. Aquaculture 220, 525-536.

Person-Le Ruyet J., Galland R., Le Roux A., Chartois H., 1997, Chronic ammonia toxicity in juvenile turbot (Scophthalmus maximus). Aquaculture 154, 155-171.

Person-Le Ruyet J., Lamers A., Le Roux A., Sévère A., Bœuf G., Mayer Gostan N., 2003a, Long-term ammonia exposure of turbot: effects on plasma parameters. J. Fish Biol. 62, 879-894.

Person-Le Ruyet J., Lacut A., Le Bayon N., Le Roux A., Pichavant K., Quéméner L., 2003b, Effects of repeated hypoxic shocks on growth and metabolism of turbot juveniles. Aquat. Living Resour. $16,25-34$.

Person-Le Ruyet J., Mahé K., Le Bayon N., Le Delliou H., Quéméner L., 2004, Effects of temperature on somatic growth and metabolism in a mediterranean population of European sea bass, Dicentrarchus labrax. Aquaculture 237, 269-280.

Person-Le Ruyet J., Le Bayon N., Gros S., 2007, How to assess fin damage in rainbow trout, Oncorhynchus mykiss? Aquat. Living Resour. 20, 191-195.

Petersen C.L., 1987, Energy budgets for juvenile rainbow trout at various oxygen concentrations. Aquaculture 62, 289-298.

Pichavant K., Person-Le Ruyet J., Le Bayon N., Sévère A., Le Roux A., Bœuf G., 2001, Comparative effects of long-term hypoxia on growth, feeding and oxygen consumption in juvenile turbot and European seabass. J. Fish Biol. 59, 875-883.

Procarione L.S., Barry T. P., Malison J.A., 1999, Effects of high rearing densities and loading rates on the growth and stress responses of juveniles rainbow trout. N. Am. J. Aquac. 61, 91-96.

Spoolder H., De Rosa G., Hoeming B., Waiblinger S., Wemelsfelder F., 2003, Integrating parameters to assess on-farm welfare. Anim. Welfare 12, 529-534.

Thurston R.V., Philipps G.R., Russo R.C., 1981, Increased toxicity of ammonia to rainbow trout ( $S$. gairdneri) resulting from reduced concentrations of dissolved oxygen. Can. J. Fish. Aquat. Sci. 2, 291-314.

Trenzado C.E., Morales A.E., de la Higuera M., 2006, Physiological effects of crowding in rainbow trout, Oncorhynchus mykiss, selected for low and high stress responsiveness. Aquaculture 258, 583-593.

Turnbull J.F., Bell A., Adams C.E., Bron J., Huntingford F.A., 2005, Stocking density and welfare of cage farmed Atlantic salmon: application of a multivariate analysis. Aquaculture 243, 121-132.

Vazanna M., Cammerata M., Cooper E.L., Parrinello N., 2002, Confinement stress in sea bass (Dicentrarchus labrax) depresses peritoneal leucocyte cytotoxicity. Aquaculture 210, 231-243.

Vijayan M.M., Ballantyne J.S., Leatherland J.F., 1990, High stocking density alters the energy metabolism of brook charr, Salvelinus fontinalis. Aquaculture 88, 371-381. 